\title{
Food and feeding ecology of Brazilian sardine (Sardinella brasiliensis) larvae from the southeastern Brazilian Bight
}

\author{
Frederico W. Kurtz ${ }^{1}$ \& Yasunobu Matsuura 2 \\ lUniversidade Santa Úrsula - Laboratório de Ictioplâncton - ICBA \\ (Rua Fernando Ferrari, 75, 22231-040 Rio de Janeiro, RJ, Brazil) \\ e-mail address: fredkurtz@alternex.com.br \\ 2Instituto Oceanográfico da Universidade de São Paulo \\ (Caixa Postal 66149, 05315-970 São Paulo, SP, Brazil) \\ e-mail address: ymatsuur@usp.br
}

- Abstract: Results from depth integrated and vertically stratified plankton samples collected in the southeastern Brazilian Bight were used to study the feeding behavior of Brazilian sardine (Sardinella brasiliensis) larvae. Sampling of the ichthyoplankton was carried out with $60 \mathrm{~cm}$ Bongo nets in the Bight during the spawning seasons of 1991/92 and 1992/93. The sampling of microzooplankton was carried out in the coastal region off Ubatuba, using the closing-type plankton net, in December 1995. The feeding study was based on a total of 901 captured larvae. Gut content analysis of the sardine larvae showed a diurnal pattern of food intake. Copepod nauplii dominated the diet of the preflexion and flexion larvae, but they were the second in abundance for the postflexion larvae which fed preferentially on copepodites and adults of Oncaea spp. Averaged feeding incidence of the 901 larvae was $37.6 \%$, but it increased to $58.5 \%$ for day-caught larvae. Seventy percent of the food particles were found in the mid-gut and food eaten showed a natural increase in digestion from fore-gut to hind-gut. Vertical distribution of microzooplankton revealed that copepod nauplii were present in densities of 10-20 ind. $\mathrm{L}^{-1}$, mainly in the upper mixed layer (0-20 $\mathrm{m}$ depth), but higher densities of copepodite and adult of Oncaea, Oithona and Paracalanus were found within and beneath the thermocline. These results show that Brazilian sardine larvae can successfully adapt their diet, feeding on the most abundant food particles in the upper mixed layer of the survey area.

- Resumo: Plâncton amostrado na região sudeste do Brasil, em coletas integradas verticalmente e estratificadas, foi utilizado no estudo do comportamento alimentar das larvas de sardinha-verdadeira (Sardinella brasiliensis). As coletas de ictioplâncton foram realizadas com rede tipo Bongo de $60 \mathrm{~cm}$ de diâmetro durante os períodos de desova de 1991/92 e 1992/93. Microzooplâncton foi amostrado na região costeira ao largo de Ubatuba em dezembro de 1995, usando uma rede de fechamento. O estudo da alimentação foi baseado em um total de 901 larvas capturadas. A análise do conteúdo do trato digestório das larvas de sardinha-verdadeira indicaram um padrão de alimentação diurno. Os náuplios de copépode dominaram a dieta de larvas em préflexão e flexão e foram o segundo item em abundância em larvas em pósflexão, que preferencialmente se alimentaram de copepoditos e adultos de Oncaea spp. Em média, a incidência alimentar das 901 larvas foi de 37,6\%, porém aumentou para $58,5 \%$ para larvas coletadas no período diurno. Setenta por cento das particulas ingeridas foram encontradas no trato médio e a digestão das partículas aumentou naturalmente desde o trato inicial até o trato final. A distribuição vertical do microzooplâncton revelou que os náuplios de copépode estiveram presentes em densidades de 10-20 ind. $\mathrm{L}^{-1}$, principalmente na camada superior de mistura (0-20 m da superfície), entretanto altas densidades de copepoditos e adultos de Oncaea, Oithona e Paracalanus foram encontradas dentro e através da termoclina. Os resultados obtidos indicaram que a larva de sardinha-verdadeira pode adaptar a sua dieta com sucesso, alimentando-se das partículas mais abundantes da camada de mistura na área estudada.

- Descriptors: Sardinella, Microzooplankton, Larval feeding, Ichthyoplankton, Southeast Brazil.

- Descritores: Sardinella, Microzooplâncton, Alimentação, Ictioplâncton, Região sudeste. 


\section{Introduction}

The Brazilian sardine (Sardinella brasiliensis) is an important fishery resource in the southeastern Brazil with a maximum catch of 230 thousand tons in 1973. Total landings declined thereafter, to 103 thousand tons in 1976 . The mean landing fluctuated around 64 thousand tons during 1990-1994 (Rossi-Wongtschowski et al., 1995), then increased to 118 thousand tons in 1997, but decreased to 22 thousand tons in 2000 . These declines were attributed to overfishing (Valentini \& Cardoso, 1991) and to recruitment failure due to high larval mortality in some years (Matsuura, 1996; 1998). The spawning of the Brazilian sardine occurs during late-spring and summer, when the water column in the bight shows a strong vertical stratification.

To understand the recruitment mechanisms of marine fish, we need to investigate the sources of larval mortality as related to starvation and predation (Hunter, 1980; Rothschild, 1986; Houde 1987). Based on the oceanographic and climatic information of the region, Bakun \& Parrish (1990) suggested the following ocean processes which assist the survival of Brazilian sardine larvae in the Bight: i) enrichment, ii) concentration of food organisms, and iii) retention of spawning products. However, the importance of the feeding ecology of sardine larvae is still speculative and no information on feeding behavior and distribution of food organisms exists for this area.

Most marine fish larvae feed selectively (Hunter, 1981; Houde \& Lovdal, 1985; Govoni et al., 1983; 1986; Young \& Davis, 1992). Food selection depends on the availability of food organisms in larval habitats. Planktonic larvae adopt a sinuous feeding posture and then strike prey at close range in order to feed (Hunter, 1981), so the swimming capacity and mouth size of larvae are also important factors which influence the larval diet. The first food of anchovy and sardine larvae consists primarily of copepod nauplii of 50-100 $\mu \mathrm{m}$ diameter (Arthur, 1976). The size of their food increases as the larvae grow.

The objective of this paper is to analyse the diet and ontogenetic changes in feeding behaviour of sardine larvae in relation to food availability in larval habitat in the southeastern Brazilian Bight.

\section{Materials and methods}

The samples used in this paper were collected during the two survey cruises conducted by the R/V. "Prof. W. Besnard" on the southeastern Brazilian Bight in the austral summers of December 1991 and January 1993. Ichthyoplankton samples were collected with $60 \mathrm{~cm}$ Bongo nets at 110 stations in the area between Cabo Frio $\left(23^{\circ} \mathrm{S}\right)$ and Cabo de Santa Marta Grande $\left(29^{\circ} \mathrm{S}\right)$. Temperature and salinity were measured using a CTD cast.

Plankton samples taken with the fine mesh net $(0.333 \mathrm{~mm})$ were preserved in a $10 \%$ buffered formalin solution. Of the 110 sampling stations, 47 were positive for sardine larvae on the December 1991 cruise and 60 were positive in January 1993 (Fig. 1). All the sardine larvae from the positive stations were used for stomach content analysis. When many sardine larvae were collected at one station, only 15 larvae of different sizes were selected for stomach contents analysis.

One sampling cruise was conducted in the coastal region off Ubatuba in December 1995, when there was a strong vertical stratification of the water column, to study the density of microzooplankton and its vertical distribution. A $46 \mathrm{~cm}$ closing plankton net with a $60 \mu \mathrm{m}$ mesh was used. A digital flowmeter was attached to measure the water volume filtered. The net was towed vertically at each $10 \mathrm{~m}$ depth interval at $0.8-1.0 \mathrm{~m} \mathrm{sec}^{-1}$. Four radials perpendicular to the coast with five stations each were sampled along the coast between São Sebastião and Ubatuba. Hydrographic data were obtained with a CTD cast. The plankton samples were preserved in $10 \%$ buffered formalin solution. After measurement of the displacement volume of plankton, the samples were split into small fractions using the cylinder plankton splitter (Motoda, 1959). Identification of zooplankton was made in accordance with the literature (Björnberg, 1963; Björnberg et al., 1994; Boltovskoy, 1981; Trégouboff \& Rose, 1957). Zooplankton density was determined by the number of organisms per litre of sea water.

The larval body length (BL) was measured to the nearest $0.01 \mathrm{~mm}$ by the ocular micrometer attached to the stereoscopic microscope. The developmental stage of the sardine larvae was defined by the degree of curvature of the distal end of the notochord (Ahlstrom et al., 1976): preflexion stage $=3.0-6.9 \mathrm{~mm} \mathrm{BL}$, flexion stage $=$ $7.0-10.9 \mathrm{~mm} \mathrm{BL}$, and postflexion stage $=11.0-16.0$ $\mathrm{mm} \mathrm{BL}$.

The entire digestive tract of each sardine larva was removed from the body and put on the slide glass with two drops of mixed solution of $4 \%$ formalin and glycerine $(1: 1)$ which facilitated the dissection of the digestive tract and the visualization of food particles. Bengal rose was used to colour the food particles. The digestive tract was separated into three parts: fore-gut, mid-gut, and hind-gut. Food particles were identified to the lowest taxonomic level and counted for each part of the gut. The width of food particles found in the digestive tract was 
level and counted for each part of the gut. The width of food particles found in the digestive tract was measured to the nearest $0.01 \mathrm{~mm}$, using the ocular micrometer. The degree of digestion was classified in three stages: initial = no visual digestion, intermediate $=$ partial digestion of exoskeleton, and final $=$ only exoskeleton visible.

Feeding incidence is the percentage of larvae with food particles in the gut. Three indices were used to evaluate the importance of each food item: i) frequency of occurrence (FO\%) which measures the percentage of all stomachs with food in which each food type occurred, ii) numerical frequency percentage (NF\%) which measures the percentage that each food type contributed to the total number of food items in all stomachs, and iii) index of relative importance (IRI) which is a product of combination of the percentage and numerical frequency occurrences of each food item (Wallace, 1981). Diet compositions of different developmental stages were compared using the percent similarity method (Schoener, 1970).

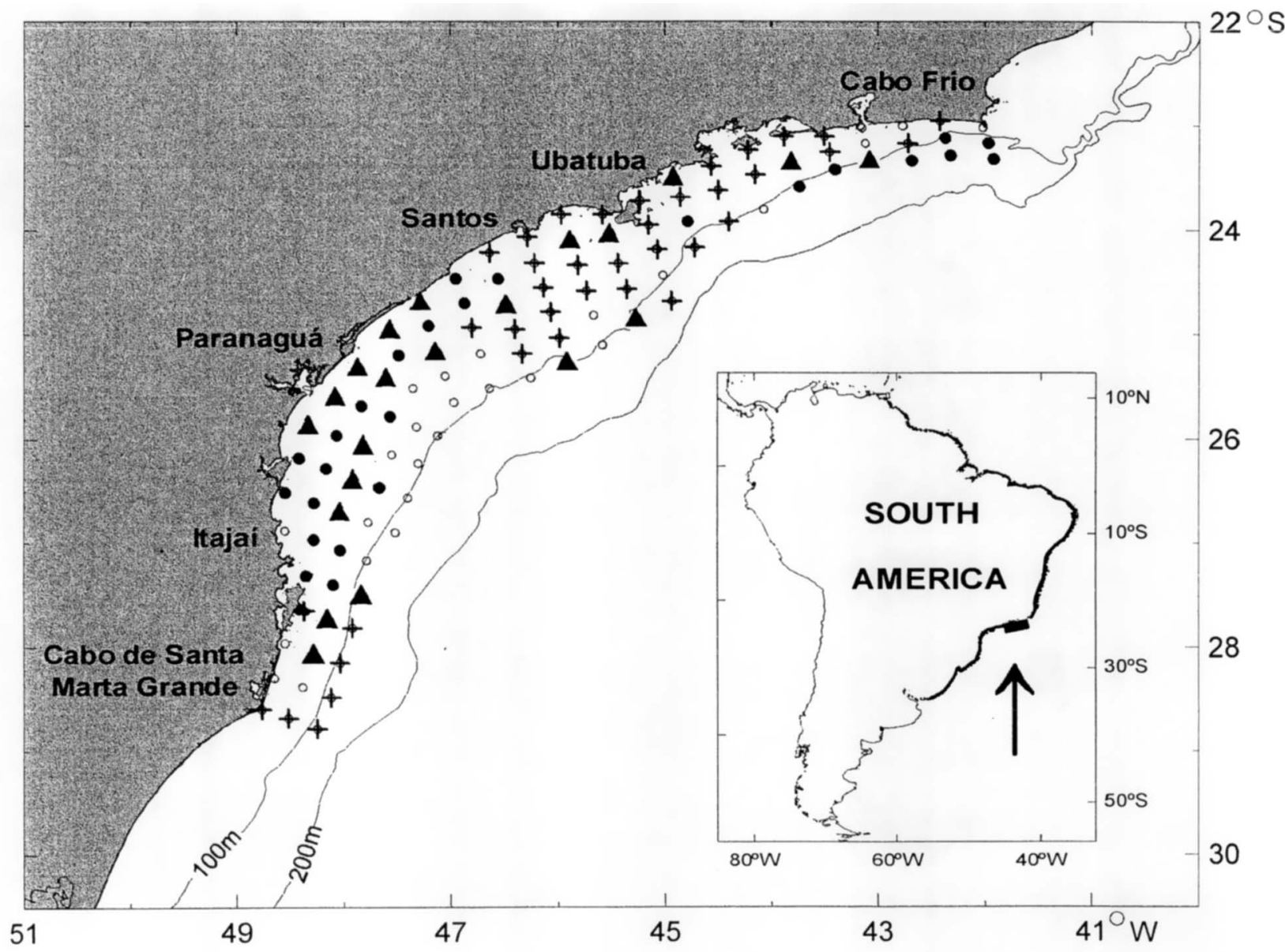

Fig. 1. Location of sampling points along the southeast Brazilian Bight, showing occurrence of Sardinella brasiliensis larvae during December 1991 cruise (solid circle), January 1993 cruise (cross) and both cruises (triangle).

\section{Results}

\section{Physical environment}

During the December 1991 and January 1993 cruises, a strong vertical stratification, characteristic of the Bight during the austral summer (Matsuura, 1986; Castro \& Miranda, 1998), was observed in the water column. The warm and low-saline Coastal Water (CW) $\left(22-25^{\circ} \mathrm{C}, 34.8\right.$ $36.2 \mathrm{psu}$ ) is confined to the coastal region and the surface layer of the entire continental shelf is 
Central Water (SACW), which occupies the deep layer of the upper continental slope, intrudes onto the continental shelf floor and reaches the coastal region in late spring and summer, thus forming a sharp thermocline between the warm TW/CW and the cool $\mathrm{SACW}\left(12-18^{\circ} \mathrm{C}, 35.2-36.0 \mathrm{psu}\right)$ in the intermediate layer.

The bottom thermal front between the $\mathrm{CW}$ and SACW runs along the coast on the $30-50 \mathrm{~m}$ isobath line, starting near Itajaí and reaching the coast north of Ubatuba. This bottom thermal front, identified by the $18^{\circ} \mathrm{C}$ isotherm, changes its position annually according to the intensity of the intrusion of the SACW which correlates closely to the summer meteorological conditions in the Bight (Matsuura, 1996). The horizontal distribution of the surface (10 $m$ depth) temperature on both cruises showed that the intrusion of the SACW was strong, forming a coastal upwelling near Ubatuba in December 1991 and January 1993 (Fig. 2).

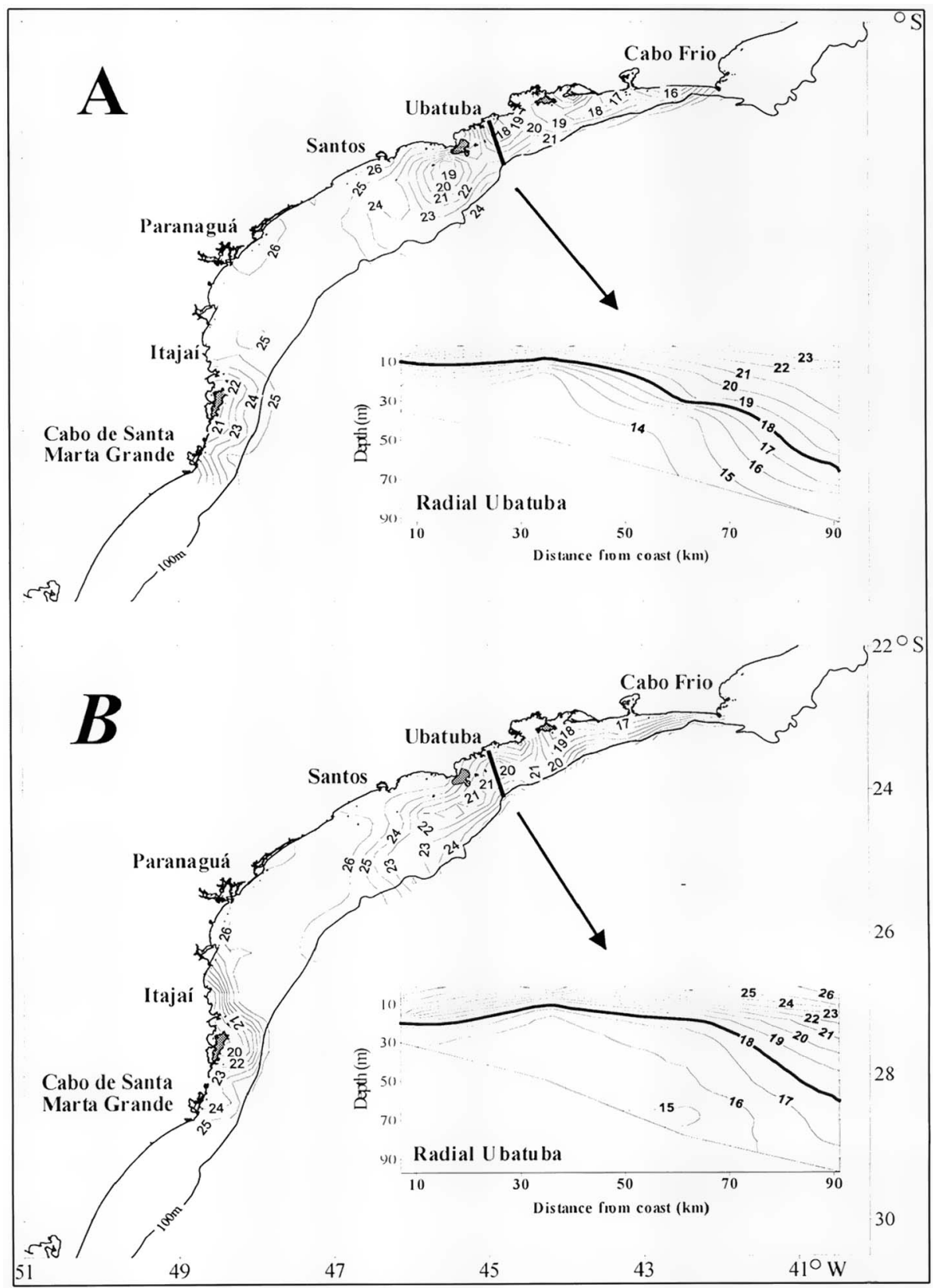

Fig. 2. Isotherms $\left({ }^{\circ} \mathrm{C}\right)$ at $10 \mathrm{~m}$ depth during December 1991 (a) and January 1993 (b) cruises along southeast Brazilian Bight, including vertical profiles of temperature off Ubatuba region. The $18^{\circ} \mathrm{C}$ isotherm delimits the cool South Atlantic Central Water (SACW) thermal front. 


\section{Feeding incidence}

The presence of food in the digestive tract indicated that most feedings (99.8\% of larvae) occurred during the period from 06:00 to 19:00 hours (local time) (Fig. 3). For the analysis of feeding ecology, the results of the two survey cruises were combined, as there was no significant difference between the food items from each (Mann-Whitney test: $\left.U=20<U_{0.05(2), 7,7}=41\right)$. The average feeding incidence was observed in $37.8 \%$ of the 901 larvae analysed (Table 1). For the 584 larvae collected during the day-time the feeding incidence increased to $58.5 \%$. Because the stations with sardine larvae with food in the digestive tract were distributed throughout the survey area, no specific tendency in the distribution pattern of feeding larvae was found.

The frequency of feeding incidence by size of sardine larvae showed a high incidence $(60-80 \%)$ in small preflexion stage larvae, a decrease in the incidence with an increase in size and the lowest incidence $(20 \%)$ in postflexion (16 mm BL) larvae (Fig. 4). The spike in frequency $(70 \%)$ in $13 \mathrm{~mm} \mathrm{BL}$ may be caused by small number (3) of larvae analysed. Consequently we can observe a constant decrease of feeding incidences from preflexion to postflexion larvae: $\quad$ (preflexion $=68.5 \%$; $\quad$ flexion $=40.4 \%$; postflexion $=25.7 \%$ ).

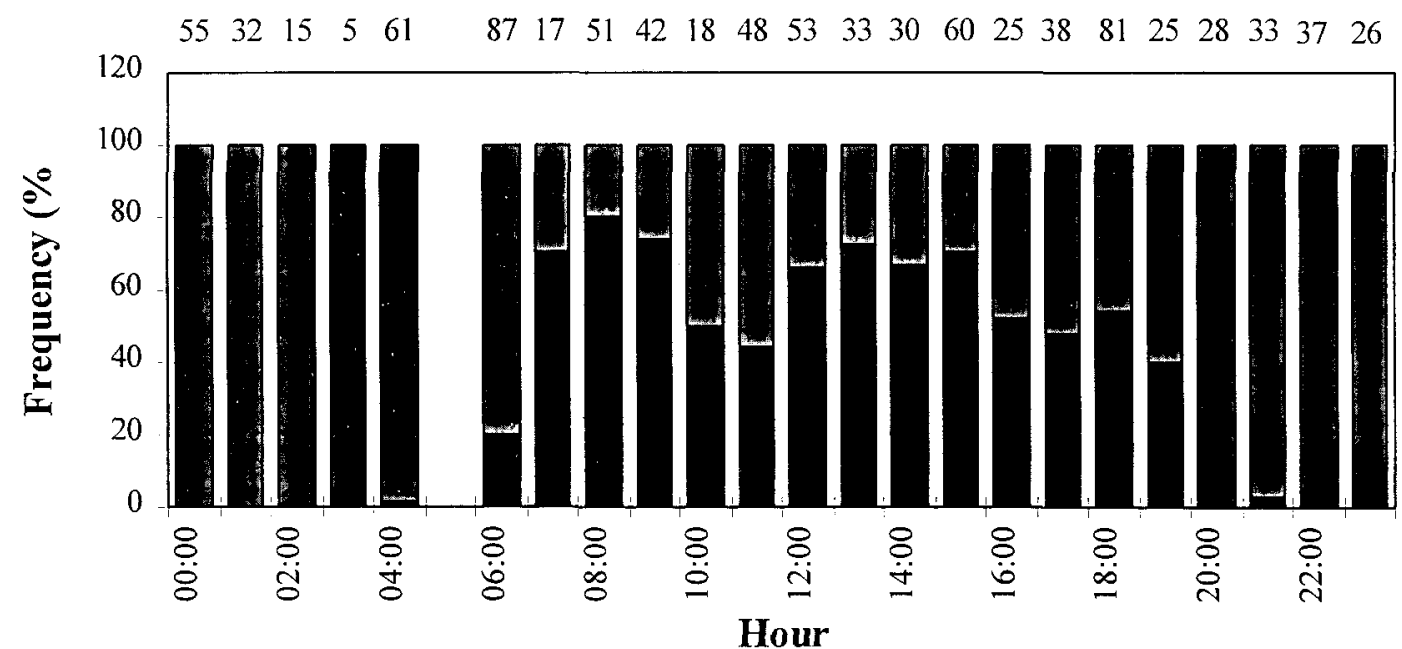

Fig. 3. Diurnal feeding patterns of Sardinella brasiliensis $(n=901)$. Number of larvae analyzed by time interval indicated at the top of each bar.

Table 1. Number of Sardinella brasiliensis larvae collected and examined by cruise, and feeding incidence (\%).

\begin{tabular}{cccccc}
\hline \multirow{2}{*}{ Cruise } & \multicolumn{2}{c}{ Total larvae } & & \multicolumn{2}{c}{ Larvae } \\
\cline { 2 - 3 } \cline { 5 - 5 } & sampled & examined & & with food & without food \\
\hline December 1991 & 2402 & 335 & & $30.7 \%$ & $69.3 \%$ \\
January 1993 & 3700 & 565 & & $41.9 \%$ & $58.1 \%$ \\
\hline
\end{tabular}




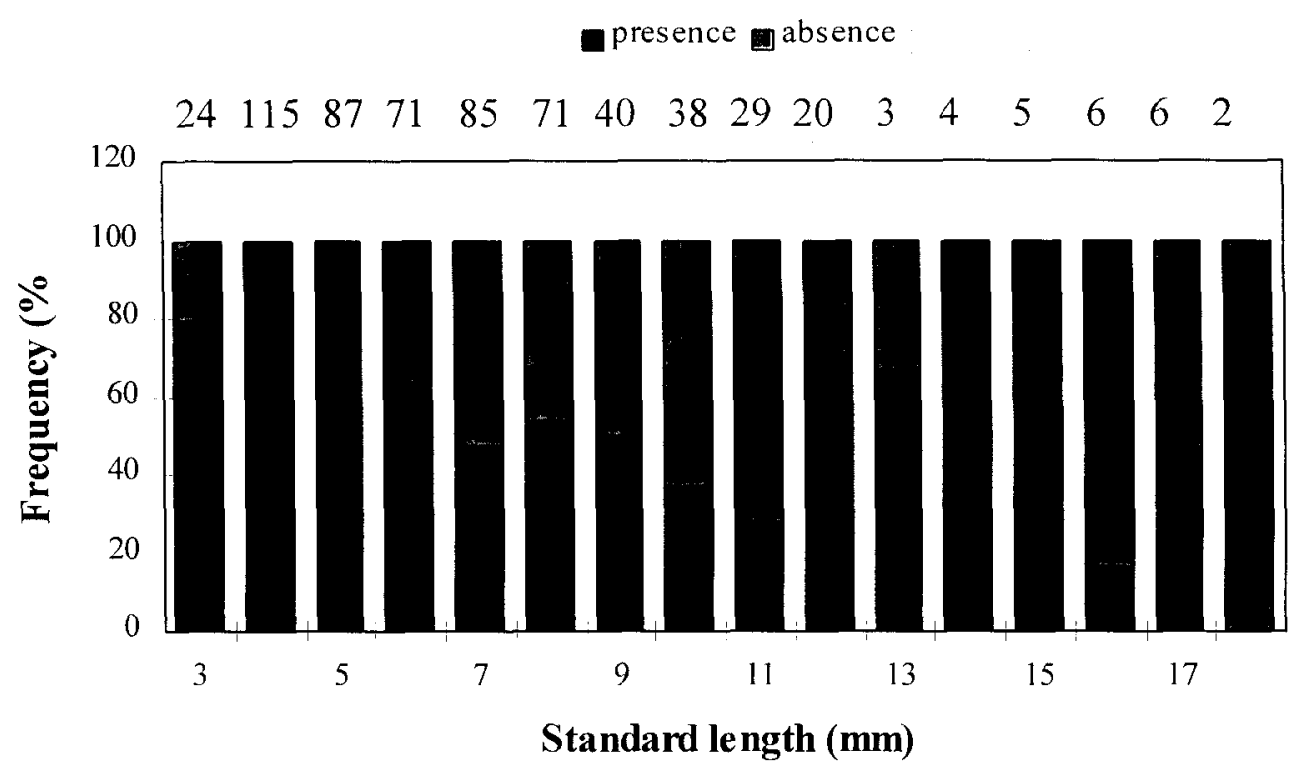

Fig. 4. Occurrence of food organisms in gut related to larvae size class $(n=606)$. Number of larvae analyzed by size class at the top of each bar. Only day-time (06:00-18:00h) collected larvae included.

\section{Change in food composition with size}

The food composition showed a dominance of copepod nauplii in all indices (FO\% $=86.7$; $\mathrm{NF} \%=78.7$; IRI $=6823.3$ ), indicating a strong preference for this food item (Table 2). Invertebrate eggs were the second most frequent food with $\mathrm{FO} \%=$ $18.2, \mathrm{NF} \%=7.3$ and IRI $=137.5$. Other items found in the digestive tract were various copepods and phytoplankton with $\mathrm{FO} \%$ and $\mathrm{NF} \%$ of less than 10. The food composition of the sardine larvae increased its spectrum with growth. The copepod nauplii were the main diet of the preflexion and flexion larvae, but came second in the diet of postflexion larvae. The dominant foods of the postflexion larvae were copepodites and adults of Oncaea spp. Invertebrate eggs were the second most important food for the preflexion and flexion larvae, but they were less frequent in postflexion larvae. Schoener's index was calculated for the diet composition of different developmental stages. The results showed that the diet overlap decreased with size and the largest index was observed as between preflexion and flexion stages $(a=0.86)$ (Table 3).
Table 2. Frequency of occurrence (FO\%), numerical frequency $(\mathrm{NF} \%)$ and index of relative importance (IRI) of food items in gut of Sardinella brasiliensis larvae $(n=340)$.

\begin{tabular}{lccc}
\hline Food item & & & \\
\cline { 2 - 4 } & FO\% & NF\% & IRI \\
\hline Copepod nauplii & 86.7 & 78.7 & 6823.3 \\
Inyertebrate eggs 1 & 18.2 & 7.3 & 137.5 \\
Oithona & 8.3 & 2.7 & 22.6 \\
Oncaea & 5.6 & 1.8 & 16.5 \\
Calanoida & 4.9 & 1.8 & 14.4 \\
Corycaeus & 2.7 & 0.8 & 3.4 \\
Phytoplankton & 5.1 & 1.9 & 9.7 \\
Others $(<5.0)$ & 17.9 & 6.1 & 21.4 \\
\hline
\end{tabular}

(1) Mostly copepod eggs, although those of other invertebrates may have been included. 
Table 3. Schoener index (a), showing trophic overlap between developing stages of Sardinella brasiliensis larvae.

\begin{tabular}{lc}
\hline \multicolumn{1}{c}{ Stages } & $a$ \\
\hline Preflexion/Flexion & 0.86 \\
Preflexion/Postflexion & 0.47 \\
Flexion/Postflexion & 0.57 \\
\hline
\end{tabular}

\section{Digestion of prey organisms}

The percentages of food found in the different parts of the digestive tract showed a significant variation, $70.0 \%$ of all food particles being found in the mid-gut. Only $2.0 \%$ of foods were found in the fore-gut and $28.0 \%$ in the hind-gut. Three degrees of digestion of food were found in the larvae taken during the day-time and the final stage of digestion was dominant at most times of the day (Fig. 5). One larva taken at 04:00 had only food in the initial stage of digestion and another larva taken at 22:00 had only food in the final stage of digestion. The advance of the digestion stage in different parts of the digestive tract showed a natural tendency to increase from fore-gut to hind-gut (Fig. 6). The foregut contained only food in the initial stage of digestion, but the mid-gut had $50 \%$ of its food in the final stage. The food found in the hind-gut showed more than $80 \%$ of its food in the final stage of digestion.

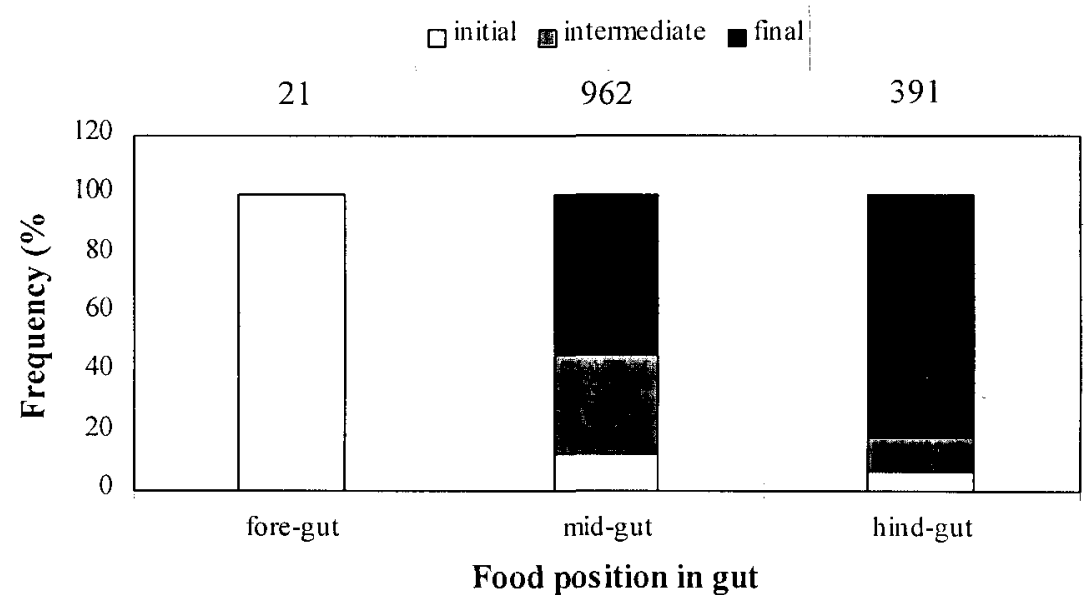

Fig. 5. Digestion degree of food items of Sardinella brasiliensis larvae $(n=340)$ by sampling time. Number of food items analyzed at the top of each bar.

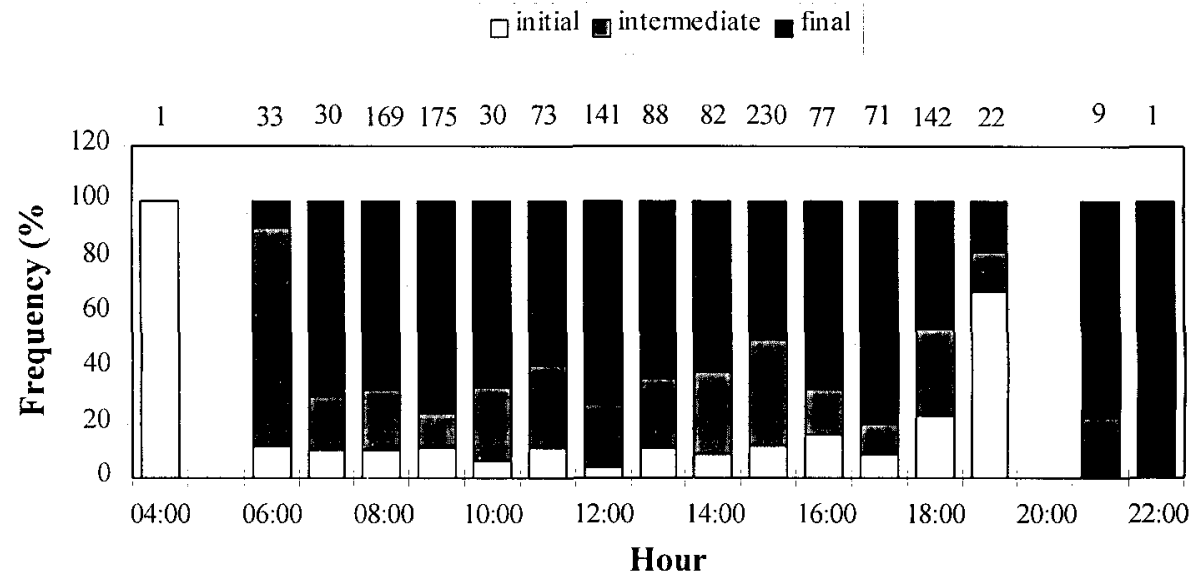

Fig. 6. Frequency distribution of digestion degrees (initial, intermediate, final) of digestive tract (fore-gut, mid-gut, hind-gut) of Sardinella brasiliensis larvae $(n=340)$. Number of food items at the top of each bar. 


\section{Prey size in relation to size}

The size of the food particles found in the preflexion larvae ranged from 30 to $100 \mu \mathrm{m}$ with a mean size of $48.7 \mu \mathrm{m}$ (s.d. $=13.6 \mu \mathrm{m}$ ). The size spectrum of food particles increased in size from the flexion stage $(7.0 \mathrm{~mm})$, to a maximum size of $350 \mu \mathrm{m}$ found in the postflexion larva of $16.0 \mathrm{~mm}$ BL.

\section{Vertical distribution of microzooplankton}

Of the 50 taxa identified only the taxonomic groups which attained more than $10 \%$ of the frequency index (FO\%) or the numerical frequency index $(\mathrm{NF} \%$ ) were considered as potential food items for the sardine larvae. They are, in order of abundance, copepod nauplii, invertebrate eggs, copepodites and adults of Oithona spp., Oncaea spp. and Paracalanus spp. (Table 4).

The highest density of copepod nauplii (17.2 ind. $\mathrm{L}^{-11}$ ) was found in the surface layer $(0-10 \mathrm{~m})$ at station 2 in the first radial, followed by the same layer at station 1. In the third radial the highest density ( 20 ind. $\mathrm{L}^{-1}$ ) was found in the upper mixed layer at station 1 and all higher densities were observed within the upper mixed layer. In general the higher densities of the copepod

Table 4. Mean densities and range of densities (in parentheses) of microzooplankton taxa (ind. $\mathrm{L}^{-1}$ ) from 84 samples by isobaths range and sampling depth.

\begin{tabular}{|c|c|c|c|c|c|c|}
\hline $\begin{array}{c}\text { Isobaths range } \\
\text { (m) }\end{array}$ & $\begin{array}{l}\text { Sampling } \\
\text { depth }(m)\end{array}$ & Copepod nauplii & $\begin{array}{c}\text { Invertebrate } \\
\text { eggs }\end{array}$ & Oithona & Oncaea & Paracalanus \\
\hline \multirow[t]{6}{*}{$22-32$} & $0-10$ & 23.0 & 0.5 & 3.9 & 7.0 & 1.6 \\
\hline & & $(13.4-36.5)$ & $(0.1-1.4)$ & $(1.3-5.5)$ & $(5.8-8.0)$ & $(0.4-2.7)$ \\
\hline & $10-20$ & 9.9 & 0.3 & 1.4 & 10.1 & 0.7 \\
\hline & & $(6.5-11.8)$ & $(0.1-0.6)$ & $(0.7-2.0)$ & $(1.8-19.6)$ & $(0.3-1.0)$ \\
\hline & $20-30$ & 10.0 & 0.2 & 1.2 & 8.6 & 0.7 \\
\hline & & $(10.0)$ & $(0.2)$ & $(1.2)$ & $(8.6)$ & $(0.7)$ \\
\hline \multirow[t]{8}{*}{$33-42$} & $0-10$ & 15.6 & 1.2 & 2.5 & 5.9 & 1.1 \\
\hline & & $(9.5-26.3)$ & $(0.2-3.8)$ & $(1.3-4.7)$ & $(2.1-7.5)$ & $(0.5-2.4)$ \\
\hline & $10-20$ & 15.4 & 0.5 & 1.3 & 9.0 & 2.5 \\
\hline & & $(2.6-34.3)$ & $(0.2-1.3)$ & $(0.8-2.1)$ & $(2.2-18.4)$ & $(0.7-4.6)$ \\
\hline & $20-30$ & 9.6 & 0.2 & 1.5 & 9.5 & 3.4 \\
\hline & & $(2.1-16.6)$ & $(0.0-0.7)$ & $(0.2-2.4)$ & $(6.4-16.0)$ & $(0.2-7.7)$ \\
\hline & $30-40$ & 1.4 & 0.2 & 0.3 & 4.9 & 0.7 \\
\hline & & (1.4) & $(0.2)$ & $(0.3)$ & $(4.9)$ & $(0.7)$ \\
\hline \multirow[t]{8}{*}{$43-48$} & $0-10$ & 12.5 & 0.4 & 1.8 & 2.6 & 2.4 \\
\hline & & $(4.3-19.7)$ & $(0.1-0.8)$ & $(0.8-3.7)$ & $(0.4-6.2)$ & $(0.1-5.1)$ \\
\hline & $10-20$ & 8.4 & 0.2 & 2.2 & 6.2 & 1.6 \\
\hline & & $(2.7-12.2)$ & $(0.1-0.3)$ & $(0.5-4.0)$ & $(1.4-11.0)$ & $(0.7-2.6)$ \\
\hline & $20-30$ & 5.7 & 0.1 & 1.2 & 6.9 & 2.0 \\
\hline & & $(2.3-12.1)$ & $(0.0-0.1)$ & $(0.2-2.3)$ & $(2.5-12.0)$ & $(0.8-4.1)$ \\
\hline & $30-40$ & 3.2 & 0.3 & 0.4 & 10.1 & 2.5 \\
\hline & & $(1.0-6.6)$ & $(0.0-0.6)$ & $(0.1-1.0)$ & $(2.5-23.0)$ & $(0.8-6.9)$ \\
\hline \multirow[t]{7}{*}{$57-66$} & $0-10$ & 9.6 & 0.1 & 1.2 & 1.6 & 1.7 \\
\hline & & $(4.0-16.1)$ & $(0.1-0.2)$ & $(0.3-2.9)$ & $(0.1-4.8)$ & $(0.2-4.2)$ \\
\hline & $10-20$ & 6.1 & 0.1 & 1.9 & 3.8 & 3.1 \\
\hline & & $(2.9-14.8)$ & $(0.0-0.2)$ & $(1.1-3.6)$ & $(1.2-10.4)$ & $(0.1-7.6)$ \\
\hline & $20-30$ & 5.1 & 0.1 & 1.4 & 3.1 & 2.1 \\
\hline & & $(2.0-9.3)$ & $0.0-0.2$ & $0.5-2.6$ & $1.5-5.8$ & $1.5-2.9$ \\
\hline & $30-40$ & 2.0 & 0.1 & 0.5 & 3.0 & 1.3 \\
\hline
\end{tabular}


Table 4. Cont.

\begin{tabular}{|c|c|c|c|c|c|c|}
\hline $\begin{array}{l}\text { Isobaths range } \\
(\mathrm{m})\end{array}$ & $\begin{array}{l}\text { Sampling } \\
\text { depth (m) }\end{array}$ & Copepod nauplii & $\begin{array}{c}\text { Invertebrate } \\
\text { eggs }\end{array}$ & Oithona & Oncaea & Paracalanus \\
\hline & & $(1.2-3.0)$ & $(0.0-0.3)$ & $(0.3-0.8)$ & $(1.1-7.5)$ & $(0.5-1.7)$ \\
\hline & $40-50$ & 2.4 & 0.7 & 0.5 & 5.1 & 1.6 \\
\hline & & $(1.1-4.2)$ & $(0.0-1.2)$ & $(0.3-0.7)$ & $(0.8-13.5)$ & $(1.0-2.9)$ \\
\hline & $50-60$ & 1.5 & 0.2 & 0.3 & 3.8 & 1.2 \\
\hline & & $(0.6-2.4)$ & $(0.0-0.4)$ & $(0.2-0.4)$ & $(1.2-6.4)$ & $(1.2-1.3)$ \\
\hline \multirow[t]{12}{*}{$67-74$} & $0-10$ & 8.3 & 0.1 & 1.0 & 1.2 & 1.0 \\
\hline & & $(2.2-14.7)$ & $(0.0-0.2)$ & $(0.6-1.5)$ & $(0.3-1.9)$ & $(0.1-2.2)$ \\
\hline & $10-20$ & 6.9 & 0.0 & 0.9 & 3.7 & 1.5 \\
\hline & & $(0.7-15.5)$ & $(0.0-0.1)$ & $(0.2-1.3)$ & $(0.5-6.1)$ & $(0.4-2.7)$ \\
\hline & $20-30$ & 5.2 & 0.0 & 2.4 & 4.0 & 4.3 \\
\hline & & $(2.3-7.8)$ & $(0.0)$ & $(0.1-6.5)$ & $(0.9-8.0)$ & $(0.2-10.5)$ \\
\hline & $30-40$ & 4.1 & 0.0 & 0.9 & 2.1 & 1.2 \\
\hline & & $(1.5-8.1)$ & $(0.0-0.1)$ & $(0.2-2.5)$ & $(1.0-4.7)$ & $(0.5-2.4)$ \\
\hline & $40-50$ & 2.7 & 0.2 & 0.6 & 1.8 & 0.9 \\
\hline & & $(1.2-4.5)$ & $(0.1-0.2)$ & $(0.3-1.1)$ & $(0.6-3.2)$ & $(0.2-1.4)$ \\
\hline & $50-60$ & 2.2 & 0.3 & 0.6 & 2.6 & 1.0 \\
\hline & & $(0.8-3.4)$ & $(0.0-0.8)$ & $(0.2-1.2)$ & $(0.4-4.7)$ & $(0.4-1.7)$ \\
\hline
\end{tabular}

nauplii were observed in the upper mixed layer above the thermocline (Fig. 7). On the other hand the high densities of adults of three copepod species (Oithona, Oncaea and Paracalanus) were found both inside and beneath the thermocline at offshore stations.

\section{Discussion}

The average feeding incidence of the Brazilian sardine larvae was $37.8 \%$ during the two sampling cruises. This relatively low incidence value has also been observed in other clupeids. Arthur (1976) obtained $26.0 \%$ of feeding incidence for the California sardine (Sardinops sagax). For the larvae of Clupea harengus and Sprattus sprattus from the North Sea the feeding incidence was $23.7 \%$ and $26.0 \%$, respectively (Last, 1980). The feeding incidence of Sardina pilchardus larvae was $27.8 \%$ in the Bay of Biscay (Conway et al., 1994). Nakata (1995) reported a feeding incidence of $50 \%$ for the Japanese sardine (Sardinops melanostictus) larvae collected during day-time in the Kuroshio Current. The feeding activities of Brazilian sardine larvae were observed mainly during day-time, so if we consider only the larvae taken during day-time, the feeding incidence attained a value of $54.7 \%$.

Low feeding incidence, ranging from 5 to
$52 \%$, was also observed in many engraulid species (Berner, 1959; Arthur, 1976; Sanches \& Manazza, 1994; Vasconcellos et al., 1998). The cause of this low feeding incidence can be related to the structure of the digestive tract of clupeoids (Hay, 1981). The long, straight digestive tract of this group facilitates evacuation of food particles during sampling and on preservation with formalin (Blaxter \& Holliday, 1963; June \& Carlson, 1971). In the case of Perciform and Pleuronectiform larvae, which have a looped digestive tract, the feeding incidence ranged from 60 to 90\% (Last, 1980; Young \& Davis, 1990; 1992; Sanchéz-Velasco \& Norbis, 1997; Grover, 1998).

The low percentage $(<5 \%)$ of food in the fore-gut was attributed to the histological and functional structure of this region (O'Connell, 1976). He observed that the fore-gut was formed by cuboidal epithelial cells and scattered mucous cells and a coat of transverse muscle fibre which serves simply to transmit food to the midgut, but not for digestion (Silva, 1990).

A decrease in the feeding incidences with growth of clupeoid larvae is common within the size range used in this study (Arthur, 1976; Roja de Mendiola, 1974; Ciechomski, 1967). Thereafter, it tends to increase due to an increasing swimming capacity and mouth size. 

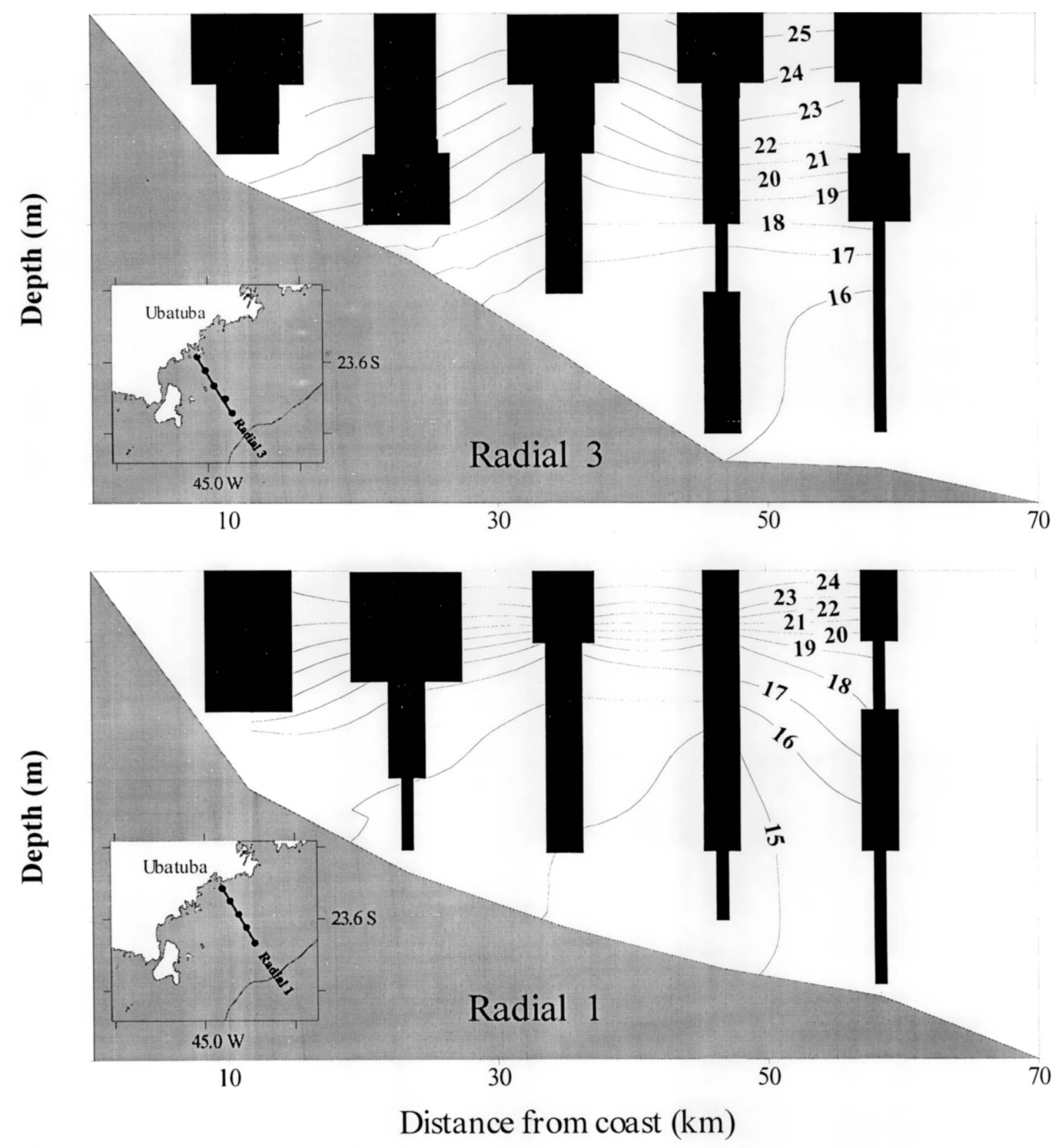

$>15.0$

$10.1-15.0$

$5.1-10.0$

$2.1-5.0$

$<2.0$ ind./L

Fig. 7. Vertical distribution of copepod nauplii (ind. $\mathrm{L}^{-1}$ ) and temperature $\left({ }^{\circ} \mathrm{C}\right)$ at radial 1 (lower) and radial 3 (upper) at Ubatuba region in December 1995. Copepod nauplii indicated by horizontal blocks.

Brazilian sardine larvae (3-10 mm BL) feed principally on the copepod nauplii. The importance of the copepod nauplii was more evident in small specimens during the flexion stage. The importance of copepod nauplii decreased gradually from $7.0 \mathrm{~mm}$ BL with an increase in other food items, such as invertebrate eggs and adults of Oncaea, Calanoids and Oithona. The importance of copepod nauplii in 
marine fish larvae, especially in clupeoids, is well documented (Hunter, 1981; Blaxter \& Hunter, 1982). The frequency composition of copepod nauplii of Sardinops sagax larvae ranged from 37 to $76 \%$ (Arthur, 1976). Last (1980) reported 22\% for Clupea harengus and Sprattus sprattus larvae and Nakata (1988) observed 30-50\% for Sardinops melanostictus larvae.

The dominance of copepod nauplii in the digestive tract of Brazilian sardine larvae can be explained by the high density of copepod nauplii (1020 inds. $\left.\mathrm{L}^{-1}\right)$ in the upper mixed layer, because the sardine larvae are mainly distributed in the same zone in this region (Matsuura et al., 1992). This high density of copepod nauplii in the upper mixed layer was similar to that observed in the feeding area of the Japanese sardine larvae in the Kuroshio Current region (Nakata et al., 1994). The authors found patches of copepod nauplii of very high density (20120 inds. $\mathrm{L}^{-1}$ ) in the Kuroshio fronts, where the feeding incidence of the Japanese sardine larvae was also high (Nakata,1990). Bakun \& Parrish (1990; 1991) suggested that the presence of high density of food particles in the upper mixed layer was an important ocean process in this region serving to sustain the high survival rate and consequently the good recruitment of sardine and anchovy during the austral summer.

After hatching the small anchovy larvae are distributed in the upper mixed layer together with the Brazilian sardine larvae during late spring and summer (Matsuura et al., 1992). Matsuura \& Kitahara (1995) demonstrated that anchovy (Engraulis anchoita) larvae migrated to the deep layer with an increase in size and the postflexion larvae and juveniles were more abundant beneath the thermocline off the Cabo de Santa Marta Grande. This vertical migration is related to an increase in swimming capacity and mouth size, resulting in a change of food composition. In water columns where vertical gradients exist both in prey and predator, fish larvae must change their vertical distribution in the struggle for survival. This kind of ontogenetic vertical migration with the consequent change in food items has been observed in many other marine fish larvae (Fortier \& Harris, 1989).

The relation between the body size and width of food particles showed that the small clupeoid larvae feed mainly on small particles with an average size of $50 \mu \mathrm{m}$. Starting from flexion stage the size spectrum of food particles increased, attaining the maximum ingested food size of $350 \mu \mathrm{m}$ in the postflexion stage. This increase in food size was attributed to increasing swimming capacity with growth and consequent success in hunting larger prey (Hunter, 1972). Vasconcellos et al. (1998) observed an increase in prey size in the digestive tract with growth of Engraulis anchoita larvae in southern Brazil. In the case of Brazilian sardine larvae the increase in food size was caused by the inclusion of copepodites and adults of Oncaea, Oithona and calanoids (probably Paracalanus) in its diet. This change must be related to the selective hunting behavior of the postflexion larvae. Govoni et al. (1986) also observed these three species of copepods in food items of the larvae of Brevoortia patronus, Leiostomus xanthurus and Micropogonias undulatus in the Gulf of Mexico. They concluded that there must be selective feeding on these three copepods, as they represented only a small fraction of the zooplankton community in the area.

Our results indicate that Brazilian sardine larvae feed selectively on the copepod nauplii during preflexion and flexion stages and later change to the copepodite, adults of Oncaea spp. and other small copepod species in postflexion larvae. In spite of a lack of temporal coincidence in ichthyoplankton and microzooplankton samplings, we can conclude that the Brazilian sardine larvae feed on these microzooplankton because of their appropriate size and availability in their habitat.

\section{Acknowledgments}

This is a contribution of the Small Pelagic fish And Climate Change Project (SPACC) of the Global Ocean Ecosystem Dynamic Program (GLOBEC). The authors received a scholarship (process no. 142521/85-0: FWK) and a research fellowship (process no. 301675/82: YM) from the $\mathrm{CNPq}$ during the investigation undertaken. We also thank Dr. Jeanete M. Ramos, Director of the Santa Úrsula University, for supporting this work.

\section{References}

Ahlstrom, E. H.; Butler, J. L. \& Sumida, B. Y. 1976. Pelagic stromateoid fishes (Pisces, Perciformes) of the eastern Pacific: kinds, distribution, and early life histories and observations on five of these from the northwest Atlantic. Bull. mar. Sci., 26(3):285-402.

Arthur, D. K. 1976. Food and feeding of three fishes occurring in the California Current, Sardinops sagax, Engraulis mordax, and Trachurus symmetricus. Fish. Bull. U. S., 74(3):517-530. 
Bakun, A. \& Parrish, R. H. 1990. Comparative studies of coastal pelagic fish reproductive habitats: the Brazilian sardine (Sardinella aurita). J. Cons. int. Explor. Mer, 46(3):269-283.

Bakun, A. \& Parrish, R. H. 1991. Comparative studies of coastal pelagic fish reproductive habitats: the anchovy (Engraulis anchoita) of the southwestern Atlantic. ICES J. mar. Sci., 48(3):343-361.

Berner Jr., L. 1959. The food of the larvae of the northern anchovy, Engraulis mordax. Bull. interAmer. trop. Tuna Comm., 4:1-22.

Björnberg, T. K. S. 1963. On the marine free-living copepods off Brazil. Bolm Inst. Oceanogr., S Paulo, 13(1):3-142.

Björnberg, T. K. S.; Lopes, R. M. \& Björnberg, M. H. G. C. 1994. Chave para a identificação de náuplios de copépodos planctônicos marinhos do Atlântico sul-ocidental. Nauplius, Rio Grande, 2:1-16.

Blaxter, J. H. S. \& Hollyday, F. G. T. 1963. The behaviour and physiology of herring and other clupeoids. Adv. mar. Biol., 1:261-393.

Blaxter, J. H. S. \& Hunter, J. R. 1982. The biology of the clupeoid fishes. Adv. mar. Biol., 20:1-223.

Boltovskoy, D. 1981. Atlas del zooplancton del Atlántico Sudoccidental y método de trabajo com zooplancton marino. Mar del Plata, INIDEP. 936 p.

Castro, B. M. \& Miranda, L. B. 1998. Physical oceanography of the western Atlantic continental shelf located between $4^{\circ} \mathrm{N}$ and $34^{\circ} \mathrm{S}$ coastal segment $(4, \mathrm{~W})$. In: Robinson, A. R. \& Brink, K. H. eds. The sea. New York, John Wiley \& Sons. p. 209-251.

Ciechomski, J. D. de 1967. Investigations of food and feeding habits of larvae and juveniles of the Argentine anchovy Engraulis anchoita. CalCOFI Rep., 11:72-81.

Conway, D. V. P.; McFadzen, I. R. B. \& Tranter, P.R.G. 1994. Digestion of copepod eggs by larval turbot Scophthalmus maximus and egg viability following gut passage. Mar. Ecol. Prog. Ser., 106(3):303-309.

Fortier, L. \& Harris, R. P. 1989. Optimal foraging and density-dependent competition in marine fish larvae. Mar. Ecol. Prog. Ser., 51(1-2):19-33.
Govoni, J. J.; Hoss, D. E. \& Chester, A. J. 1983. Comparative feeding of three species of larval fish in the Northern Gulf of Mexico: Brevoortia patronus, Leiostomus xanthurus, and Micropogonias undulatus. Mar. Ecol. Prog. Ser., 13(2-3):189-199.

Govoni, J. J.; Ortner, P. B.; Al-Yamani, F. \& Hill, L. C. 1986. Selective feeding of spot, Leiostomus xanthurus, and Atlantic croaker, Micropogonias undulatus. Mar. Ecol. Prog. Ser., 28(1-2):175183.

Grover, J. J. 1998. Feeding habits of pelagic summer flounder, Paralichthys dentatus, larvae in oceanic and estuarine habitats. Fish. Bull. U. S., 96(2):248-257.

Hay, D. E. 1981. Effects of capture and fixation on gut contents and body size of Pacific herring larvae. Rapp. P.-v. Réun. Cons. perm. int. Explor. Mer, 178:395-400.

Houde, E. D. 1987. Fish early life dynamics and recruitment variability. Am. Fish. Soc. Symp., 2:17-29.

Houde, E. D. \& Lodval, J. D. A. 1985. Seasonality of occurrence, foods and food preferences of ichthyoplankton in Biscayne Bay, Florida. Estuar. coast. Shelf Sci., 18:403-419.

Hunter, J. R. 1972. Swimming and feeding behavior of larval anchovy, Engraulis mordax.. Fish. Bull. U. S., 70(3):821-838.

Hunter, J. R. 1980. The feeding behavior and ecology of marine fish larvae. In. Bardach, J. E.; Magnuson, J. J; May, R. C. \& Reinhart, J. M. eds. Fish behavior and its use in the capture and culture of fishes. ICLARM Conf. Proc., 5:287330 .

Hunter, J. R. 1981. Feeding ecology and predation of marine fish larvae. In: Lasker, R. ed. Marine fish larvae: morphology, ecology, and relation to fisheries. Seattle, Univ. Washington Press. p.3377.

June, F. C. \& Carlson, F. T. 1971. Food of the young Atlantic menhaden Brevoortia tyrannus in relation to metamorphosis. Fish. Bull., U.S., 68(3):493512 .

Last, J. M. 1980. The food of twenty species of fish larvae in the west-central North Sea. Fish. Res. Tech. Rep., MAFF Direct. Fish. Res., Lowestoft, $60: 1-44$. 
Matsuura, Y. 1986. Contribuição ao estudo da estrutura oceanográfica da região sudeste entre Cabo Frio (RJ) e Cabo de Santa Marta Grande (SC). Ciênc. Cult., S Paulo, 38(8):1439-1450.

Matsuura, Y. 1996. A probable cause of recruitment failure of the Brazilian sardine Sardinella aurita population during the $1974 / 75$ spawning season. S. Afr. J. mar. Sci., 17:29-35.

Matsuura, Y. 1998. Brazilian sardine (Sardinella brasiliensis) spawning in the southeast Brazilian Bight over the period 1976-1993. Rev. bras. oceanogr., 46(1):33-43.

Matsuura, Y.; Spach, H. L. \& Katsuragawa, M. 1992. Comparison of spawning patterns of the Brazilian sardine (Sardinella brasiliensis) and anchoita (Engraulis anchoita) in Ubatuba region, southern Brazil during 1985 through 1989. Bolm Inst. oceanogr., S Paulo, 40(1/2):101-115.

Matsuura, Y. \& Kitahara, E. M. 1995. Horizontal and vertical distribution of anchovy Engraulis anchoita eggs and larvae off Cape Santa Marta Grande in southern Brazil. Arch. Fish. mar. Sci., 42(3):239-250.

Motoda, S. 1959. Devices of simple plankton apparatus. Mem. Fac. Fish., Hokkaido Univ., 7:73-94.

Nakata, K. 1988. Alimentary tract contents and feeding conditions of ocean-caught post larval Japanese Sardine, Sardinops melanostictus. Bull. Tokai Reg. Fish. Res. Lab., 126:11-24.

Nakata, K. 1990. Abundance of nauplii and protein synthesis activity of adult female copepods in the Kuroshio front during the Japanese sardine spawning season. J. Oceanogr. Soc. Japan, 46(5):219-229.

Nakata, K. 1995. Feeding conditions of Japanese sardine larvae in and near the Kuroshio examined from their gut contents. Bull. Natl. Res. Inst. Fish. Sci., 7:265-275.

Nakata, K.; Hada, A. \& Matsukawa, Y. 1994. Variations in food abundance for Japanese sardine larvae related to the Kuroshio meander. Fish. Oceanogr., 3(1):39-49.

O'Connell, C. P. 1976. Histological criteria for diagnosing the starving condition in early post yolksac larvae of the northern anchovy, Engraulis mordax Girard. J. exp. mar. Biol. Ecol., 25(3):285-312.
Roja de Mendiola, B. 1974. Food of the larval anchoveta Engraulis ringens J. In: Blaxter, J. H. $\mathrm{S}$. ed. The early life history of fish. Berlin, Springer-Verlag. p. 277-285.

Rossi-Wongtschowski, C. L. D. B.; Saccardo, S. A. \& Cergole, M. C. 1995. Situação do estoque da sardinha no litoral sudeste e sul. Col. Meio Ambiente, Sér. Estudos Pesca. 17:1-44.

Rothschild, B. J. 1986. Dynamics of marine fish populations. Cambridge, Harvard University Press. 277p.

Sanches, R. P. \& Manazza, G. O. 1994. Estudios sobre la alimentación de larvas de anchoita (Engraulis anchoita) en relación com los frentes de marea de la región patagónica. Frente Mar., Montevideo, 15:51-65.

Sanchéz-Velasco, L. \& Norbis, W. 1997. Comparative diets and feeding habitats of Boops boops and Diplodus sargus larvae, two sparid fishes co-occurring in the northwestern Mediterranean. Bull. mar. Sci., 61(3):821-835.

Schoener, T. W. 1970. Nonsynchronous spatial overlap of lizards in patchy habitats. Ecology, 51:408-418.

Silva, A. 1990. Histomorphology of the digestive system of sardine Sardina pilchardus larvae. Port. Zool., 1(5):37-41.

Trégouboff, G. \& Rose, F. 1957. Manuel de planctologie méditerranéenne. Paris, CNRS. 207p.

Valentini, H. \& Cardoso, R. D. 1991. Análise da pesca da sardinha-verdadeira, Sardinella brasiliensis, na costa sudeste-sul do Brasil. Atlântica, Rio Grande, 13(1):45-54.

Vasconcellos, M. C.; Freire, K. F. \& Castello, J. P. 1998. Distribution patterns and feeding success of anchovy, Engraulis anchoita, larvae off southern Brazil. Sci. Mar., 62(4):385-392.

Wallace Jr., R. K. 1981. An assessment of dietoverlap indexes. Trans. Am. Fish. Soc., 110(1):72-76.

Young, J. W. \& Davis, T. L. O. 1990. Feeding ecology of larvae of southern bluefin, albacore and skipjack tunas (Pisces: Scombridae) in the eastern Indian Ocean. Mar. Ecol. Prog. Ser., 61(12): 17-29. 
Young, J. W. \& Davis, T. L. O. 1992. Feeding ecology and interannual variations in diet of larval jack mackerel Trachurus declivis (Pisces: Carangidae), from coastal waters of eastern Tasmania. Mar. Biol., 113(1):11-20.

(Manuscript received 31 January 2002; revised 15 April 2002; accepted 27 June 2002) 